\title{
Socioeconomic determinants of farm household land allocation for grass pea production in North Wollo Zone of Amhara region, Ethiopia
}

\author{
Shimeles Damene (iD ${ }^{1 凶}$, Dawit Diriba Guta ${ }^{1}$, Mohammed Assen ${ }^{2} \&$ Poshendra Satyal $^{3}$
}

Grass pea (Lathyrus sativus) is widely cultivated and consumed in Ethiopia, where its overconsumption has caused cases of lathyrism. Despite this fact, there are limited empirical studies carried out in Ethiopia on the factors driving household decision to grow grass pea and intensity of land allocation to its production. Therefore, this study was focused on exploring the determinants of smallholder farmers' land allocation to grass pea production in two districts of Ethiopian highlands. Household survey, focus group discussions and key informant interviews were used as data collection methods. These were followed by statistical analysis of quantitative data with SPSS and thematic analysis of qualitative data. The study used the Heckman selection model to investigate the determinants of household's intensity of land use for grass pea production. The data revealed that farmers in the study area annually allocated about $26 \%$ of their farm plots size to grass pea production. Household's landholding size, age of household head and the head's primary school attendance have statistically significant and positive effect on the size of land allocation to grass pea production. Farmers also switched to grass pea production due to its tolerance to drought and waterlogged soils. These all encouraged grass pea production and consumption by humans, which has resulted in lathyrism in the study area. Household access to health and farm extension services had negative and statistically significant effect on land allocation to grass pea production. Based on the findings, it is concluded that better access to markets, educational opportunities, credit facilities, family planning and farm extension services are needed to increase household awareness on crop diversification and enhance technology uptake and financial capacity. Consequently, this can help local people reduce allocation of land to grass pea production and decrease its consumption, thereby preventing the risk of lathyrism incidence.

\footnotetext{
${ }^{1}$ Center for Environment and Sustainable Development, College of Development Studies, Addis Ababa University, Addis Ababa, Ethiopia. ${ }^{2}$ Department of Geography and Environmental Studies, Addis Ababa University, Addis Ababa, Ethiopia. ${ }^{3}$ School of International Development, University of East Anglia, Norwich, UK. ${ }^{凶}$ email: shimelesdamene@yahoo.com
} 


\section{Introduction}

griculture in Ethiopia accounts for about $47 \%$ of the gross domestic product (GDP), $80 \%$ of the employment and $60 \%$ of the export income (World Bank, 2018). The cultivated land in the country is covered by cereals (75\%), pulses (15\%), oil seeds (7\%) and the rest by other crops such as root crops, vegetables, fruits and coffee (Rashid et al., 2010; Atnaf et al., 2015). Pulse crops in Ethiopia are often consumed in the form of sauce or stew with Enjera (Ethiopian pan cake) or eaten as boiled or roasted, and are important as supplementary diet. Field peas (Pisum sativum), faba beans (Vicia faba), chick peas (Cicer arietinum), grass peas (Lathyrus sativus), haricot beans (Phaseolus vulgaris) and lentils (Lens culinaris) are the major pulse crops in the country (Rashid et al., 2010; Taffesse et al., 2011; Atnaf et al., 2015). About 1\% of total cultivated land or $9 \%$ of pulse crop land in Ethiopia is covered by grass pea with some degrees of regional variations (CSA, 1996, 2018). For example, about $2 \%$ of total and $15 \%$ of pulse crop cultivated land is found in the Amhara region of Ethiopia, where the present study sites are located. This makes grass pea to be the third important cultivated pulse crop in the study region, following chick pea and faba beans, respectively (Kassie, 2011; CSA, 2018).

Apart from Ethiopia, grass pea has been among the leguminous crops grown and consumed elsewhere in Africa, Asia, Europe and South America for the last 2500 years, with some differences in cultivated area. At a global scale, land put under grass pea production is estimated at about 1.5 million ha annually that produce about 1.2 million tons of the pulse, indicating the importance of the crop (Yang and Zhang, 2005; Siddique et al., 2006; Kumar et al., 2011). Thus, despite its severe consequences on human health, grass pea remains an important crop for some segments of people of many countries (Siddique et al., 1996; Siddique et al., 2006; Kumar et al., 2011; Singh et al., 2013; Oluwole, 2015) including in Ethiopia (Getahun et al., 1999; Tekle-Haimanot et al., 2005; Urga et al., 2005; Fikre et al., 2010; Damene, 2014). Lathyrism is a health problem in Ethiopian highlands with very high prevalence rates in the Amhara region (where grass pea is largely produced) (Getahun et al., 1999; Fikre et al., 2010; Woldeamanuel et al., 2012). The production and consumption of grass pea and its associated health problem in the region is largely associated with food crop shortages emanated from drought, crop diseases and pest incidences. For instance, in the Central Ethiopian Highlands, about $0.25 \%$ of population were found to sustain health impacts of lathyrism (Tekle-Haimanot et al., 2005). Similarly, a rapid survey conducted by Damene (2014) revealed an existence of 800 (1.1\%) lathyrism cases out of the total 73,894 studied people in the Dawnt district. These authors indicated an existence of clear positive association between grass pea production and consumption (and hence its health impact) and occurrence of drought and food crop shortages in their respective study sites. The worst case of the problem is that lathyrism affects the productive age group of the population, predominantly children, youths and male adults. Thus, lathyrism is not only a health issue but also a socioeconomic concern, resulting from increased production and consumption of grass pea. This is also generally true for certain segments of the population in other parts of the world (Kumar et al., 2011).

Despite the health impacts, grass pea remains an important pulse crop grown and consumed by many farming communities in Ethiopia and other countries (Tekle, 1999). For this, farmers' decision on allocation of agricultural land to different types of crops (including grass pea) is influenced by a combination of factors. Among others, these can include socioeconomic-e.g., marketing (Mwaura and Adong, 2016); policies and strategies; physiology of crops and its resistance to environmental hazards such as pests and droughts (Wu and Brorsen, 1995; Coxhead and
Demeke, 2004), as well as other production factors such as access to agricultural inputs, extension and credit services (Chibwana et al., 2012; Gebresilassie and Bekele, 2015).

The popularity of grass pea production among some farmers is mainly attributed to its multiple use and unique character to survive under harsh environmental conditions. The grain of grass pea is used as human food and the residue as a highly nutritious livestock feed (Siddique et al., 2006; Rashid et al., 2010; Kassie, 2011; Singh et al., 2013; Atnaf et al., 2015; Thulin, 1983; Kassie, 2011). The crop gives optimal yield under harsh climatic and environmental conditions particularly under drought, water logging, heavy clayey soils (e.g., Verisols), flooding, frosting and incidences of plant diseases and pests (Tekle-Haimanot et al., 2005; Yang and Zhang, 2005: Siddique et al., 2006; Woldeamanuel et al., 2012; Dixit et al., 2016). Moreover, the crop has low input (fertiliser) requirement and does not need intensive management (Abd El Moneim et al., 2000; Getahuna et al., 2002; Nguyen et al., 2017; Yazici and Bilir, 2017).

There are also other socioeconomic factors that can influence household land use decision for crop production, such as of grass pea. These include: household size, age, dependency factor, education status and income of households (Mwaura and Adong, 2016), landholding size (Hillocks and Maruthi, 2012; Mwaura and Adong, 2016), access to credit (Nguyen et al., 2017) and available farm extension services (Greig, 2009). However, to what extent and how these factors determine household decision on land allocation for grass peas production is less understood, particularly in Ethiopia.

Irrespective of its health impact, farmers in Ethiopian highlands have continued allocating their limited available crop land resource to grass pea production (Tekle-Haimanot et al., 2005; Tekle, 1999; Woldeamanuel et al., 2012). However, there are limited empirical studies carried out in Ethiopia on the factors driving household decision to grow grass pea and intensity of land allocation to its production. In order to address this gap in research, our study was aimed at answering this main question: what are the major determinants influencing farmers' land allocation to grass pea production (despite associated health consequences with its consumption)? Exploring the underlying factors determining household land allocation to produce and consume grass pea is also crucial for developing policies that can help reduce the dependency on the crop and thus minimise associated health impacts.

\section{Materials and methods}

The study area. The study was conducted in Delanta and Dawnt districts (locally called woreda) of the Amhara region, Central Highlands of Ethiopia. The study districts are located between $11^{\circ}$ $20^{\prime}$ to $11^{\circ} 50^{\prime}$ North latitude and $38^{\circ} 40^{\prime}$ to $39^{\circ} 30^{\prime}$ East longitude (Fig. 1). Delanta district is subdivided into one urban (Wogeltena) and 34 rural kebeles (lower administrative units of Ethiopia). Dawnt district is also divided into 1 urban (named as Chet) and 14 rural kebeles. Out of these, 18 and 7 kebeles in Delanta and Dawnt districts, respectively, belong to Dega agro-climatic (cool, humid highlands) zone.

As shown in Fig. 2, the study districts have a complex topography with wide relief differences ranging from 1348 to $3658 \mathrm{~m}$ above mean sea level ( $\mathrm{m}$ amsl). The major landforms are plateau, escarpments, gorges and hills. The presence of such diverse landforms has caused the districts to have diversified agro-ecology. Based on traditional classification system (Hurni, 1998), the study area consists of kolla, weyna dega, dega agroecological zones, covering 3.0, 40.8, 41.2 and $15 \%$ of the landmass, respectively (Fig. 2). The topography and agro-ecological diversity 


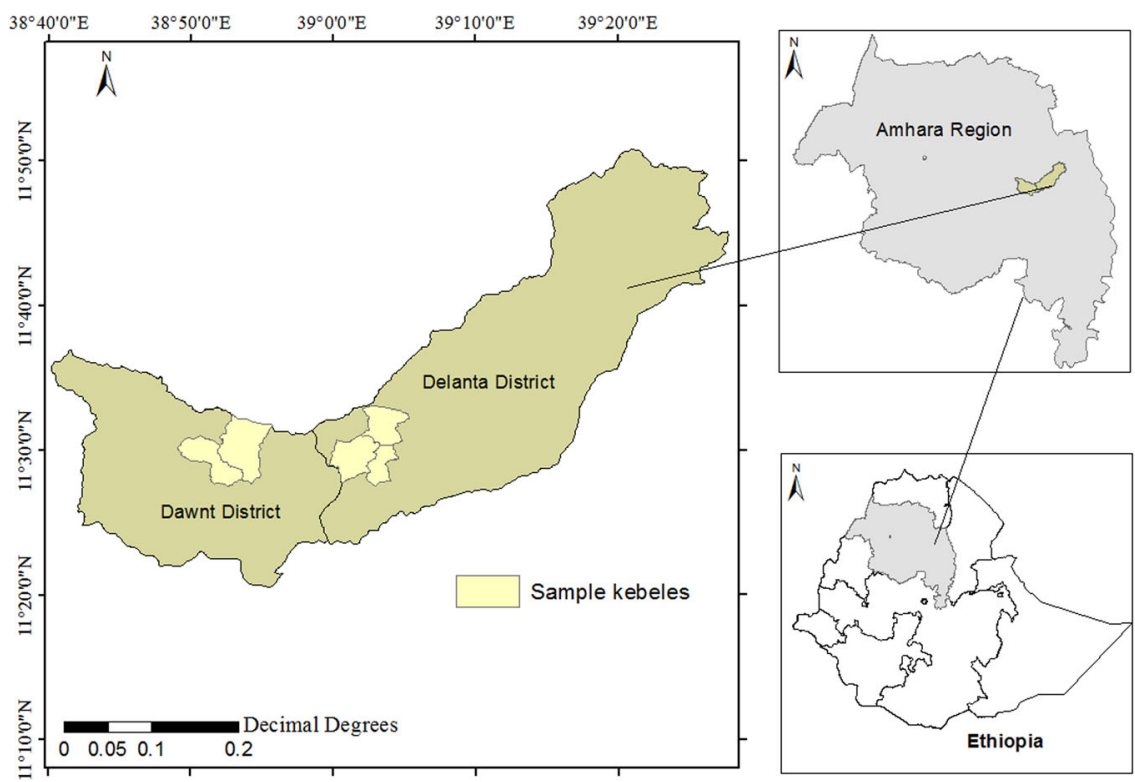

Fig. 1 Map of the study districts. Map of the study districts showing location of Amhara region (Light Grey) in Ethiopia (White), Delanta and Dawnt districts (Lime Dust) in Amhara region (Light Grey) map and Sample kebeles (light yellow) in Dawnt and Delanta districts (Source of the data/shape file: Ethiopian Central Statistical Authority, 2007).

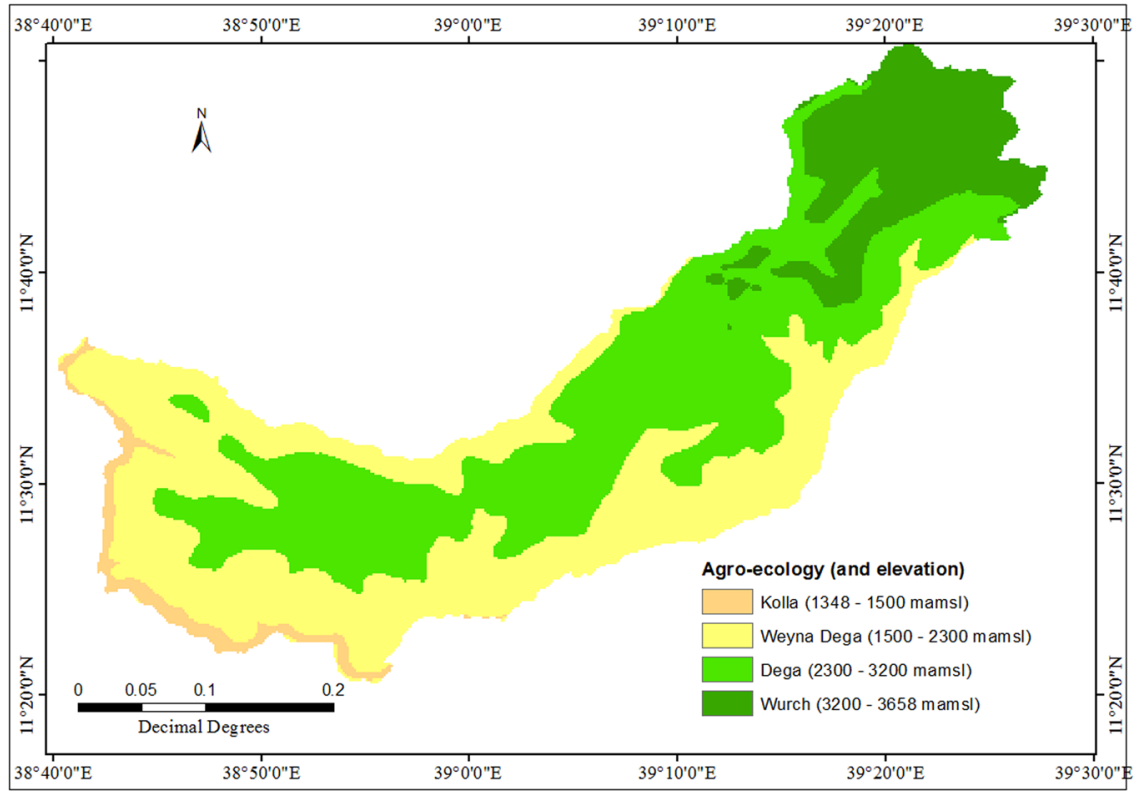

Fig. 2 Agro-ecology and elevation of study districts. The map is generated by Geographical Information System (GIS) based $30 \mathrm{~m}$ resolution digital elevation data analysis using Digital Terrain Model (DTM).

have yielded different soil types in the study districts. The steeper slope areas are dominantly covered by shallow soils mainly Leptosols and Regosols while the plateaus are covered by clayey soils, which could be described as Vertisols and Vertic Cambisols (FAO, 1984).

The Beshilo River and its biggest tributary river called Jita drain the study area that shortly joins the Abay (the Blue Nile) River. The plateau parts of these districts receive high rainfall (Fig. 3) during the main rainy season, with poor soil drainage causing water logging and inundation. Cereals and pulses are the major crop types grown in the study sites. Owing to soil properties (clayey and poor drainage characteristics of the plateau lands) and climate (cool and moist), grass pea is among the widely cultivated crop in the plateaus of study sites. Projection of CSA
(2008) data revealed that the population of Dawnt and Delanta was estimated to be 73,894 and 137,970, respectively, in 2018 .

Methods. The research applied mixed method that involved both quantitative and qualitative research design to collect pertinent data. The mixed method approach helps to triangulate and understand the contradiction between the findings from both methods (i.e., quantitative and qualitative) and yields more robust results. The quantitative method mainly relied on approaches used to collect and analyse the determinants of land use for grass pea cultivation such as socioeconomic and demographic characteristics. The qualitative research approaches aimed to validate and support the quantitative results. 


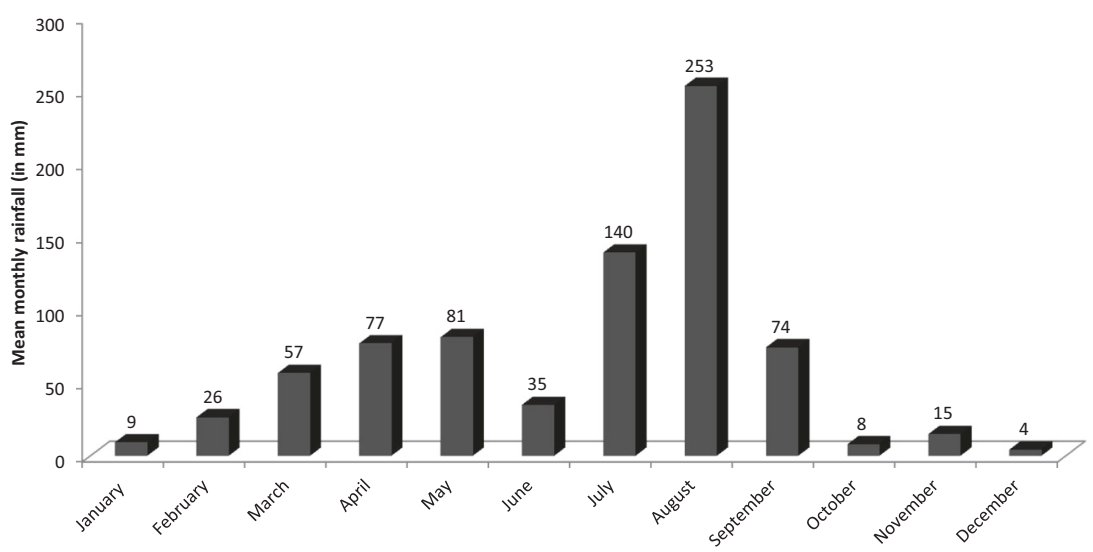

Fig. 3 Wogeltena station mean monthly rainfall (Source: Wogeltena Meteorology Station, mean monthly rainfall of 1981 to 1988 ). Due to missing data, it was not possible to cover period after 1988 in the analysis.

Data collection. Quantitative data were generated through semistructured questionnaires survey. Moreover, qualitative data was generated using focus group discussions (FGDs) and key informants interviews (KIIs). The FGDs were conducted with group of people in each sampled kebele to supplement data collected through household survey. In total, six FGDs were conducted, i.e., one FGD in each sample kebele. Each FGD consisted of 10 to 12 participants organised from people of different age, sex and social categories (children, youth, adult and elderly, men and women) and persons with lathyrism disability. FGD participant's selection was done in joint consultation with kebele administration, health extension workers and agriculture office extension agents based on pre-set criteria of the research team. KIIs were conducted with health extension workers, and development agents at kebele level, district offices of health, agriculture and lathyrism victims association's offices. In total, 13 KIIs were conducted, where KII participant's selection was based on involvement in communitybased agricultural and health extension services and vulnerability to lathyrism.

Sampling. Accordingly, using statistical formula (Cochran, 1963), we selected a sample of 384 farm household from the two districts of Delanta and Dawnt. These districts were purposefully selected owing to the relatively large proportion of land allocation for grass pea production despite the continued occurrence of lathyrism in the study sites (Damene, 2014). In total, the survey covered 384 households from the two districts, $128 \mathrm{HHs}(33 \%$ of surveyed HHs) from Dawnt and $256 \mathrm{HHs}$ from Delanta district (67\% of surveyed HHs) (Table 1).

Multi-stage sampling techniques were used to select sample kebeles. Number of sample kebeles was determined based on population of the two districts. Hence, out of the total 48 rural kebeles in the two districts, we decided to sample six kebeles. The kebeles of dega agro-ecological zone were targeted in sampling as this zone is the major production area of grass pea. Thus, the major criteria included in selecting sample kebeles from selected kebeles in the dega agro-ecology were: prevalence of lathyrism, extent of grass pea production, agro-ecological zone and the landform (i.e., plateau sites).

The agro-ecological zone and the landform of the area were generated from $30 \mathrm{~m}$ resolution digital elevation data using Digital Terrain Model (DTM) through Geographical Information System (GIS) technique. This map was used to identify potential study kebeles for the sampling. Accordingly, out of 25 kebeles in the dega agro-ecological zone of the districts, 12 kebeles (four from Dawnt and eight from Delanta) with larger proportion of flat and depression landform were shortlisted at desk review stage

\begin{tabular}{|llcr|}
\hline \multirow{2}{*}{ Table 1 Sample HHs by districts and kebeles. } \\
Name of district & Name of kebeles & \multicolumn{2}{l|}{ Sample size } \\
\cline { 3 - 4 } & & $\mathbf{N}$ & $\%$ \\
\hline Dawnt & Atsefit Yekendat & 64 & 16.7 \\
& Debir Agonat & 64 & 16.7 \\
Delanta & Subtotal & 128 & 33.3 \\
& Chew Katir & 66 & 17.2 \\
& Kachin Ara & 71 & 18.5 \\
& Baba & 60 & 15.6 \\
& Silana Tikrena & 59 & 15.4 \\
& Subtotal & 256 & 66.7 \\
& Grand total & 384 & 100.0 \\
\hline
\end{tabular}

before the actual field work commenced. Then, in the field, out of shortlisted 12 kebeles, six kebeles were purposefully sampled based on the above selection criteria using information obtained from the respective districts' agriculture and health offices. Accordingly, Atsefit-Yekendat and Debir-Agonat kebeles from Dawnt and Chew-Katir, Kachin-Ara, Baba and Silana-Tikrena from Delanta were sampled for the survey.

After the selection of sample kebeles, sampling of survey households was carried out from the list of households residing in the sample kebeles (list obtained from the respective kebele administration offices). Household sampling intervals were determined in such a way that number of households ( $\mathrm{HHs}$ ) of the sample kebele was divided by sample size allocated to the kebele. Sample size of each kebele was determined based on household number of the kebele. Then, HHs randomisation was performed indiscriminately among grass pea producers and nonproducers by lottery method from the kebele $\mathrm{HH}$ list. The first $\mathrm{HH}$ was randomly selected from the list by lottery method and then sampling continued by adding sampling interval until required sample size was attained. In the case of unavailability of the sampled $\mathrm{HH}$ head or spouse in the study area due to unforeseen circumstances (travel, death or other reasons), the samples were replaced from the list just by picking the name before or after the selected household. Survey $\mathrm{HH}$ interval calculation and sampling considered 5\% contingency to replace $\mathrm{HHs}$ that would be temporarily unavailable for the interview due to unforeseen circumstances.

Procedure. Then, enumerators were recruited and trained for the household survey from the two districts in collaboration with the two districts administration council and agriculture offices. Their 
Table 2 Description of determinants and their expected effects on intensity of land allocation to grass pea production.

\section{Variables name}

Logincome

LivestockTLU

Landholding

Wealthindex

Householdsize

Age

Gender

Headeducfirstycle

Headeducseccycle

Head high school

Credit

Farmext

Distancemkt

Perceivedcc

District

\section{Description}

Expected effect

Logarithm of income (Ethiopian Birr)

Number of livestock in TLU

Total landholding size (hectares)

Wealth index

Family size of household (number)

Age of household head (years)

Gender of household head ( $1=$ male, 0 otherwise)

Head first cycle elementary school ( $1=$ yes, 0 otherwise)

Head second cycle elementary school ( $1=$ yes, 0 otherwise)

Head high school ( $1=$ yes, 0 otherwise)

Credit access ( $1=$ yes, 0 otherwise)

Farm extension ( 1 = yes, 0 otherwise)

Distance to market $(\mathrm{km})$

Perceived climate change ( $1=$ yes, 0 otherwise)

Dummy district ( 1 = Dawnt, 0 otherwise)

\section{Expe}

$+$

$+$

$+/-$

$+/-$

$+/-$

$-$

$-$

$-$

$-$

$-$

$-$

$+/-$ training focused on survey procedures and methods, questionnaire and ethical consideration. In order to avoid communication gap among enumerators, respondents and researchers, the survey questionnaire was translated into Amharic (local language) at the preparation stage. Each question of the household interview questionnaire used for the survey was written both in Amaric and English that ran together on continuous line so as to reduce any language induced communication gap. With all these, the research team together with the data collectors first conducted a questionnaire pre-test in Arka Chinka (non sample) kebele of Delanta district, and then it was improved before administration. Then, primary quantitative and qualitative data were collected through household survey, focus group discussion (FGDs) and key informant interviews (KIIs). Researchers intensively supervised the survey. In this study, crop and livestock production survey covered only 1 year, i.e., the period between June 2015 and May 2016.

Ethical consideration. As the study involved human participants, the research proposal and assessment tools were submitted and approved by Addis Ababa University for compliance with the rules and regulation of the university code of ethics in line with national and international ethical standards. Accordingly, before starting the survey/interview, enumerators informed each respondent about the purpose of the study, data management strategy and confidentiality statement and asked for the willingness of each interviewee telling that they can quit at any time whenever they feel uncomfortable. Thus, our enumerators interviewed 384 respondents who gave their full consent for the interview and allowed those who refrained ( 7 individuals), thanking them for coming to the interview. Moreover, codes were used during analysis and reporting instead of respondents' name or other features that could lead to the identification of the individual. As agreed with respondents, the researchers used all records only for research purpose and kept them strictly confidential at all time, as per national and international ethical guidelines.

Data analysis. Final data cleaning was done before encoding the data in SPSS pre-made data entry template. This was followed by quality assessment of the entered data by the research team using randomly selected (10\%) raw data to guide the entry and make corrections. The qualitative and quantitative data collected through household survey, FGDs and KIIs were analysed and interpreted using different methods. A thematic analysis of the qualitative data was used to substantiate and explain quantitative data results obtained from statistical analysis. The quantitative data generated through household survey were analysed using descriptive statistics (SPSS) and Heckman two-stage selection model in STATA version 16.

Estimation of survey households' wealth status. The wealth status of the survey households was assessed from different asset holdings, which is a locally used criterion to measure wealth, as revealed through community FGDs. Household asset variables that were used to measure wealth included: owning of corrugated iron roof house, a pair or more plough oxen, two or more cows, mobile or landline (wireless) phone, bicycle, horse or mules, solar or biogas lamp and number of food sufficient months. All variables except number of food sufficient months were coded as categorical (Yes $=1$ and No=0), while food sufficient months were given scale value ranging between 0 and 1 by dividing number of food sufficient months by 12. Then the wealth status of the household $(\mathrm{WsHH})$ was estimated by adding the variables and dividing number of considered variables (8) and then multiplying the result by hundred as give in the equation below (Eq. 1).

$$
\mathrm{WsHH}=\left(\left(\sum_{i}^{8} X i\right) / 8\right) * 100
$$

where: $i=$ asset type

Econometric model specification. The decision to produce and the intensity of land allocated to grass pea production by a household was estimated using the Heckman two-stage models. The Heckman model was selected as a plausible model because of the suspected selectivity bias. According to the model, it is presumed that a household follows a two-stage decision process. The first stage describes farm household's choice decision on whether to grow grass pea or not. This model is estimated using the probit equation (Eq. 2). In the second stage, farm households make the decision on the intensity of land to produce grass pea if they choose to grow the crop in the first stage. This is the outcome equation specified in Eq. (3). Hence, there is selectivity issue as the intensity of land allocated to grass pea is contingent upon household selection decision of growing (or not growing) the crop. The final equation (Eq. 4) that we estimated takes into account the selectivity problem.

Following Heckman (1979), the model is specified as below:

$$
Y i=\beta X_{i}+\varepsilon_{i}
$$


where $Y_{i}$ represents the intensity (amount) of land allocated to grass pea,

$X_{i}$ denotes observed household $i^{\text {th }}$ variables affecting amount of land used for grass pea by household, and $\varepsilon_{i}$ represents the stochastic disturbance term.

It is presumed that $Y_{i}$ is observed only for households who decided to grow grass pea. Therefore, the sample selection in this model relates to the fact that household should be a grower of grass pea to observe the amount of land they allocate to grass pea production.

The selection equation relates to the decision or choice to grow or not to grow grass pea, which is specified as:

$$
G_{i}=\gamma Z_{i}+\mu_{i}
$$

where $G_{i}$ is the choice to grow grass pea $\left(G_{i}=1\right.$, if household grew grass pea, 0 otherwise), $Z_{i}$ represents independent variable in the selection model, and $\mu_{i}$ denotes an error term.

The model can be specified as:

$$
E\left(Y_{i} / G_{i}=1, X_{i}\right)=E\left(Y_{i} / G_{i} X_{i} \mu_{i}\right)=\beta X_{i}+E\left(\varepsilon_{i} / \mu_{i}>-\gamma Z_{i}\right)
$$

Heckman approached this problem by considering $E\left(\varepsilon_{i} / \mu_{i}>-\gamma Z_{i}\right)$ as omitted variable problem and proposed that estimating the omitted variable could solve the problem of sample selection bias (Heckman, 1979). In general, the model can be written as:

$$
E\left(\varepsilon_{i} / \mu_{i}>-\gamma Z_{i}\right)=\rho_{\varepsilon u} \sigma_{\varepsilon} \lambda_{i}\left(Z_{i} \gamma\right)=\beta_{\lambda} \lambda_{i}\left(-Z_{i} \gamma\right)
$$

Where, $\lambda_{\mathrm{i}}\left(-\gamma Z_{i}\right)$ is the inverse Mill's ratio evaluated at the indicated value and $\beta_{\lambda}$ is unknown parameter equal to $\rho_{\varepsilon u} \sigma_{\varepsilon}$.

Identification of independent variables. The detailed description of variables controlled in the model and hypothesised effect on intensity of land allocation to grass pea is presented in Table 2. Household wealth and income are expected to reduce land use for grass pea but the effect of livestock ownership and landholding is expected to be positive because grass pea straw is used for cattle feeding. Following Hillocks and Maruthi (2012) and Mwaura and Adong (2016), landholding size is a key factor affecting household decision on the choice of crop type grown.

Higher level of education is hypothesised to reduce land use for grass pea since it improves people's knowledge and awareness of the repercussion of grass pea use (Getahuna et al., 2002). Positive perception of grass pea also induces increase in land use for its cultivation since the crop is drought resistant (Getahuna et al., 2002). Similarly, farmers closer to market centres are expected to allocate more land to grass pea because the crop is grown for cash. Access to credit is also a critical factor determining farmers land use decision (Nguyen et al., 2017). Farmers who have contact with agricultural agents or extension workers are likely to get more training to diversify their crop and gain more awareness about the adverse effect of grass pea on health and are thus expected to allocate less amount of land to the crop (see Greig, 2009).

\section{Results and discussion}

Socioeconomic profiles of survey households. Table 3 presents the descriptive statistics of explanatory variables used in the model. The per capita household average landholding size was small, only 0.89 hectare, which is less than 1 hectare of the national average household landholding size. About $95 \%$ of the household head were male and $32 \%$ of them attended elementary second cycle (grade 5-8) school, and 15 and 7\% attended elementary first cycle (grade 1-4) and secondary first cycle (grade 9-10) school, respectively, whereas the remaining $31 \%$ were illiterate, i.e., unable to read and write. Household heads who

\begin{tabular}{|c|c|c|}
\hline Variables name & Mean & Std. dev. \\
\hline Logincome & 8.6 & 1.2 \\
\hline LivestockTLU & 2.25 & 1.3 \\
\hline Landholding & 0.89 & 0.58 \\
\hline Wealthindex ${ }^{a}$ & 34.17 & 17.12 \\
\hline Wealthinsqr & 1460.16 & 1284.94 \\
\hline Household size & 5.73 & 1.76 \\
\hline Age & 47.6 & 12.83 \\
\hline Gender ${ }^{b}$ & 0.95 & 0.21 \\
\hline Headeducfirstycle & 0.15 & 0.36 \\
\hline Headeducseccycle & 0.32 & 0.47 \\
\hline Head high schoolc & 0.07 & 0.25 \\
\hline Creditd & 0.23 & 0.42 \\
\hline Farmext ${ }^{\mathrm{e}}$ & 0.75 & 0.43 \\
\hline Distancemkt & 6.18 & 3.15 \\
\hline Perceivedcc ${ }^{f}$ & 0.82 & 0.38 \\
\hline Districtg & 0.33 & 0.47 \\
\hline \multicolumn{3}{|c|}{$\begin{array}{l}\text { aComputed from household ownership (corrugated house, two or more ox, two or more con } \\
\text { radio, TV, cycle, biogas, solar panel) and proportion of months they consume from their. } \\
\text { bFemale-headed household. } \\
\text { cExcluded category: illiterate head. } \\
\text { dExcluded category: no access to credit. } \\
\text { eExcluded category: no access to farm extension worker. } \\
\text { 'Excluded category: not perceived climate change. } \\
\text { gExcluded Dalenta and Dawnt districts. }\end{array}$} \\
\hline
\end{tabular}

Table 3 Descriptive statistics of explanatory variables used in the model.

Table 4 Wealth rank of survey households.

\begin{tabular}{llcrc} 
Wealth rank & Index range & Frequency & Percent & Valid percent \\
\hline 1. Very poor & $0-25$ & 143 & $37.1 \%$ & $37.1 \%$ \\
2. Poor & $25.1-50$ & 192 & $49.9 \%$ & $49.9 \%$ \\
3. Medium & $(50.1-75)$ & 49 & $12.7 \%$ & $12.7 \%$ \\
4. Rich & $(75.1-100)$ & 1 & $0.3 \%$ & $0.3 \%$ \\
Total & & 385 & $100.0 \%$ & $100.0 \%$ \\
\hline
\end{tabular}

attended formal education accounted for 54\%, while $15 \%$ were educated through non-formal education systems such as religious and adult education. This indicates an existence of a higher literacy rate than the national average (49.1\%) as reported in 2015 (UNESCO, 2015). Credit access in the study area was low, only $23 \%$ had got access to credit during the survey period. About $75 \%$ and $36 \%$ of the households had contact with farm extension workers and health extension workers, respectively. On an average, farmers travel about $6 \mathrm{~km}$ to the nearest market place. About $82 \%$ of the farmers had perceived the change in climatic condition such as reduced rain and increased temperature.

As shown in Table 4, the wealth status of survey households was estimated based on local wealth ranking method and it was found that majority $(87 \%)$ of survey households were rated as very poor $(37.1 \%)$ and poor $(49.9 \%)$.

Grass pea production and land allocation in relation to other crops. The descriptive analysis of 2015-2016 crop production (Table 5) revealed that different types of crops were grown in the study area. Like most farm households in Ethiopia, the smallholder farmers produce different crop types. Accordingly, wheat was grown by $90 \%$ of sampled households followed by grass pea, which were among widely cultivated crops by $75 \%$ (288 HHs) respondents. Like other smallholder farmers of the country, diversification proportion has been common practice in which the survey households also cultivated teff (57\%), lentils (47\%), 
Table 5 Area covered by different crops in 2015/16 (June 2015-May 2016).

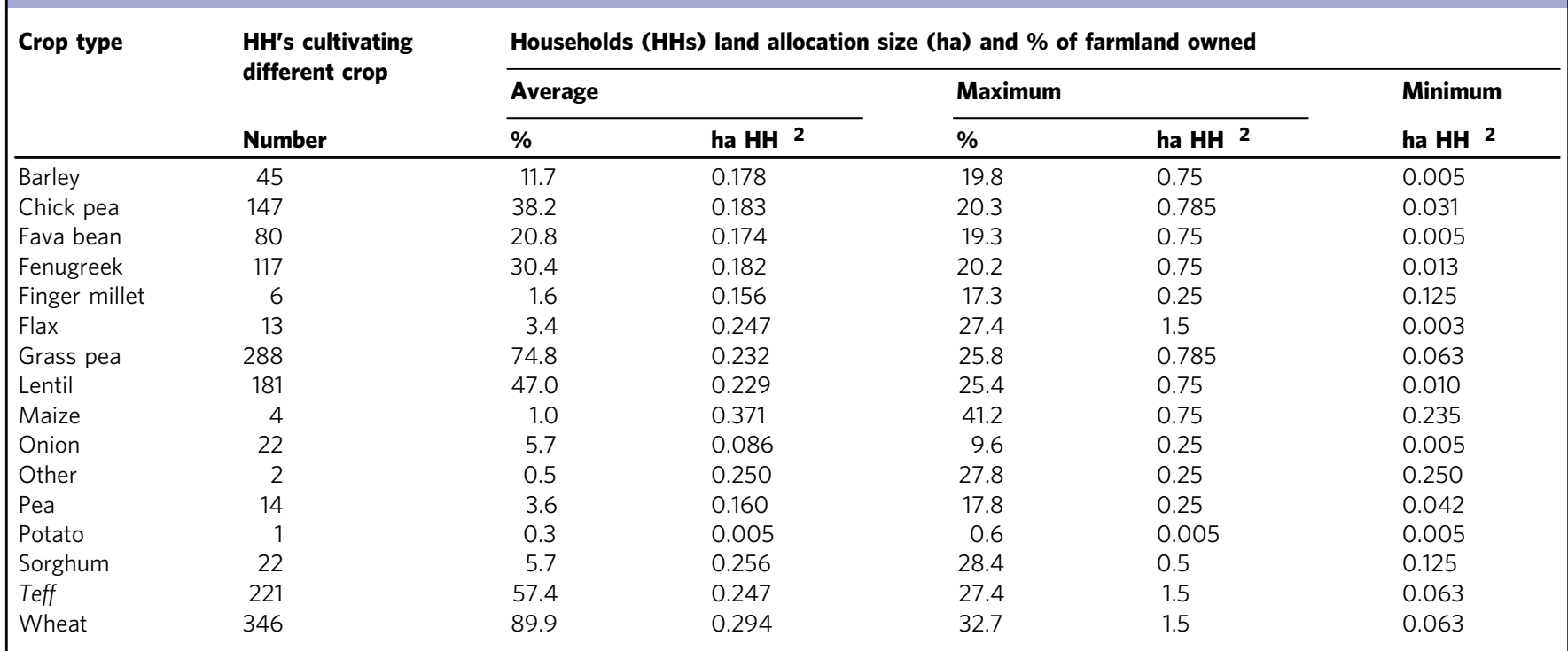

chick pea (38.2\%), fenugreek (30.4\%) and faba bean $(20.8 \%)$ in the year under the survey. When the FGD participants were asked why they produce different type of crop even under small farmland holding, they elaborated thus: “... diversification of crop production is embedded in our culture, so as to reduce weather and crop disease related risks and fulfil household's needs for different purposes and food type. This is the reason why crop diversification is practiced even by households who own a small plot of farmland".

The size of land allocated from own farmland by survey households vary from plots of $1 / 16$ th ha to $3 / 4$ th hectare. In terms of average size of farmland allocated for grass pea production on own holding, it was the third next to teff $(27 \%)$ and wheat (33\%), respectively (Table 5). On an average, the individual smallholder farmers allocated about $26 \%$ of size of farmland they owned to grass pea production.

On other hand, more size of farmland was allocated for grass pea production by some households despite the fact that all owned small farmland size. This allocation of large land to grass pea production has been related to accessing more farmland through share cropping modality. In such system, the sharing farmer will use the farmland in fixed term (mostly for one or two cropping seasons) and equally share the produce without considering its costs of production. In connection to this, in the study year (June 2015-May 2016), survey households on average cultivated 0.9 ha of farmland with grass pea using both own holding and shared in farmland (Table 6). In fact, some farmers allocated up to over 2 ha of farmland for grass pea cultivation.

As the FGDs discussants illustrated: “... the average land size might not be more than a quarter of hectare from own holding. However, some farmers cultivated up to 2 ha by obtaining land through sharecrop arrangement modality. This kind of land accessions allows much land allocation for grass pea production. Farmers who entered share cropping arrangement opt to plant grass pea since the crop doesn't require much labour for land preparation and management, needs limited agricultural input, and grows well in residual soil moisture. ... Female-headed households would often lease out or give the land for share cropping if they do not have male (boys or relatives) who could perform farming for them. In such cases, farmers who take share cropping arrangements with female-headed households would prefer grass pea production to other types of crops".

\begin{tabular}{|c|c|c|c|c|c|c|}
\hline \multirow[t]{2}{*}{ Area (ha) } & \multicolumn{2}{|c|}{$\begin{array}{l}\text { Male } \\
\text { headed HHs }\end{array}$} & \multicolumn{2}{|c|}{$\begin{array}{l}\text { Female- } \\
\text { headed HHs }\end{array}$} & \multicolumn{2}{|c|}{$\begin{array}{l}\text { Overall } \\
\text { households }\end{array}$} \\
\hline & Number & $\%$ & Number & $\%$ & Number & $\%$ \\
\hline$\leq 0.25$ & 40 & 11.0 & 1 & 5.0 & 41 & 10.6 \\
\hline $0.251-0.5$ & 68 & 18.6 & 8 & 40.0 & 76 & 19.7 \\
\hline $0.501-0.75$ & 78 & 21.4 & 2 & 10.0 & 80 & 20.8 \\
\hline $0.751-1.00$ & 68 & 18.6 & 2 & 10.0 & 70 & 18.2 \\
\hline-1.50 & 72 & 19.7 & 5 & 25.0 & 77 & 20.0 \\
\hline $1.501-2.0$ & 22 & 6.0 & 2 & 10.0 & 24 & 6.2 \\
\hline$>2.01$ & 17 & 4.7 & 0 & 0.0 & 17 & 4.4 \\
\hline Total & 340 & 100 & 20 & 100 & 385 & 100 \\
\hline
\end{tabular}

This shows that grass pea is among the most important and widely cultivated crop that competes considerably land size allocation with other crops grown in the area and, as a result, it is produced by most (75\%) of the survey respondents. Therefore, farmers who have shortages of labour and agricultural inputs choose to grow crops such as grass pea that demand less labour and less inputs, as also suggested by other researchers (e.g., Girma et al., 2011; Woldeamanuel et al., 2012).

Household determinants for land allocation to grass pea production. The results from Heckman two-stage model on household's decision to grow and the intensity of land allocation to grass pea production is presented in Table 7 . The dependent variable is the size/intensity of land used for grass pea production by HHs during the 2015-2016 crop seasons. In this part, our discussion focuses on the results of the outcome equation. The results show that there was a positive correlation between the two error terms (i.e., $\varepsilon_{i}$ and $\mu_{i}$ ) (Table 7). Moreover, the wald $\chi^{2}$ test shows that the correlation between the two stochastic disturbance terms is statistically significant $(P<0.05)$. These show that there is a selectivity problem in the model. This justifies the appropriateness of the use of Heckman model.

Access to farm extension service. Farm extension service is a key tool that has been widely practiced in Ethiopian agriculture 
Table 7 Model result of land use for grass pea production by households (note: dependent variable is the size of land in ha).

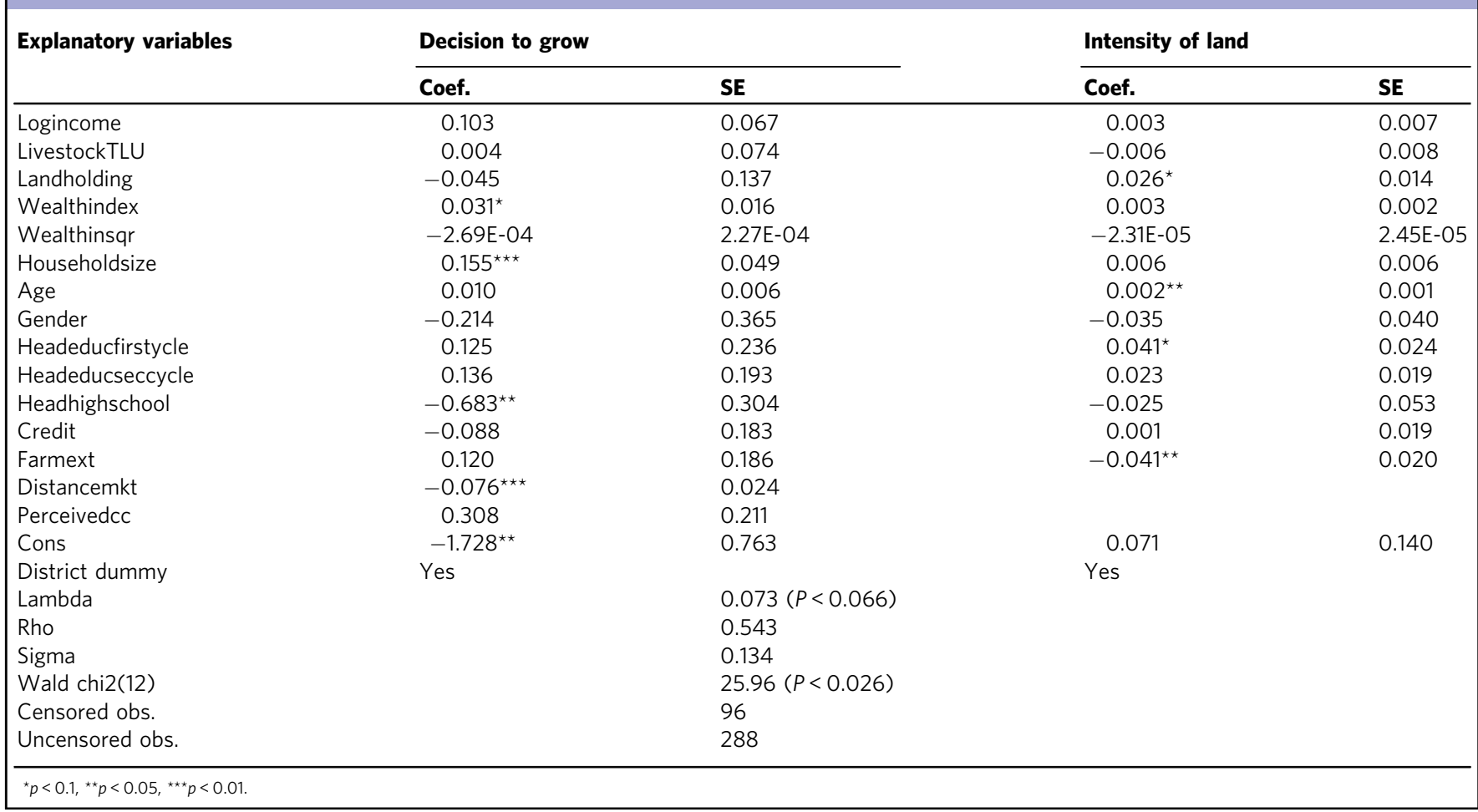

system to increase farmers' awareness and to promote modern agricultural practices. In our model, we controlled this variable to investigate how it affects farmers' decision of growing grass pea and intensity of land for it. Our findings indicated that household access to farm extension services is significant $(P<0.1)$ and was a negative determinant of size of land used by household to grow grass pea. This implies that farm households who have access to extension service allocated less size of their land to grass pea production as compared to counterpart households who have no access to farm extension service. The result from the Heckman model (Table 7) shows that the size of land allocated to grass pea by household was about 0.04 hectares less for those who had access to farm extension service compared to counterparts who had no access to the service. The most plausible explanation for this finding is that access to farm extension services increases farmers' awareness on the negative health impacts of grass pea, which arises from continued reliance on consumption of grass pea; thus, they tend to use less size of their land to produce this crop. Moreover, farmers who have access to farm extension service are expected to be trained on crop diversification and hence they shift to the cultivation of other crops. Agricultural extension service is among the other factors determining farmer's decision making on the type of crops to be cultivated (Greig, 2009).

Landholding size. For smallholder farmers, land is one of the critical inputs in agriculture. Our results indicated that size of household landholding is one of the key factors determining household land allocation to grass pea production. Landholding size was found to have significant $(P<0.1)$ and positive effect on farm size of land used for growing grass pea by a household. Land allocated to grass pea increases by about 0.03 ha when the landholding size of household increases by 1 ha, keeping other factors constant. This implies that farmers who have more land allocate more area for grass pea cultivation. In this regard, Hillocks and Maruthi (2012) and Mwaura and Adong (2016) have also confirmed the influence of households' farmland holding size determining the type of crop to be cultivated. Considering the current state of Ethiopian market, farmers with large farmland size, could benefit more if they shift to production of cash crops such as chick pea, as compared to sticking to production of grass pea.

Education level of household head. Another important factor that influenced household land use for grass pea production was education level of household head. Our findings revealed that household head's education level positively impacts on their land use for grass pea production. Nevertheless, only first cycle elementary school education attendance was found to have significant $(P<0.1)$ effect on land use for grass pea production by farm households. The results of this study indicated that land allocated to grass pea was 0.04 hectare higher for heads who attended first cycle elementary school compared to counterparts who were headed by illiterate individual. In the study area, the results from the FGD indicated that grass pea is considered as one of the cash crops or market-oriented crops. Since it is a high yielding and drought tolerant crop, educated heads may be more aware of the market opportunities and hence grow higher income generating crops. However, our results showed that the probability of growing grass pea is statistically significant $(P<0.05)$ and lower for heads in secondary school compared to illiterate counterparts. Our results are thus in line with Mwaura and Adong (2016) who also reported that the education status of household heads determines decision of crop to be cultivated. This may also be induced from the fact that better educated heads are aware of the health impacts of grass pea dependency. Hence, provision of formal and informal education opportunities can help reduce grass pea cultivation and consumption and thus also address associated health and socioeconomic problems.

Age of household head. The age of household head is one of the key determinants of household land allocation decision. Our results revealed that household head's age has significant $(P<0.05)$ 
and positive effect on land allocated to production of grass pea by households, indicating that as the age increases, the size of land allocated to grass pea increases. As the age of household head increases by 1 year, the size of land allocated for grass pea production increases by about 0.002 hectare, keeping other factors constant. There are three plausible explanations for the positive effect of age of the household head on land allocated to grow grass pea. First, older farmers have more size of land whereas younger ones usually bequest limited amount of land from their parent or rent it from other people. Second, as the FGD participants highlighted, grass pea is less labour intensive. Old heads likely face labour constraint as their children may depart from parents due to marriage or other factors. Hence, they may choose to allocate more of their land to grass pea cultivation. Finally, as our FGD participants revealed and data on victim of lathyrism indicated the incidence is high among young people and the fear of the problem is low among old people. Hence, our results indicate that the households headed by an old individual may prefer to allocate greater size of land to grass pea cultivation. Therefore, intensifying extension services and education opportunities for young age members can reduce dependence on grass pea production and consumption.

Household wealth. Wealth of household was not a significant factor to affect the intensity of land use for grass pea. Hillocks and Maruthi (2012) and Oluwole (2015) indicated that poor households opted grass pea production. However, our results revealed that household wealth was positively associated with decision of growing grass crop. The probability of growing grass pea increased with increase in wealth of household and was found to be statistically significant $(P<0.01)$. This may be due to the fact that wealthy households obtained more share land as they were able to cover other cost of production (input and labour) compared to the poor and middle income households. However, as discussed above, wealthy households who mostly obtained share lands from poor, particularly female-headed households, tended to switch grass pea planting whenever they had labour and time shortages.

Household size. Household size was found to have insignificant effect on size of land use for growing grass pea. However, it was found to have positive and significant $(P<0.01)$ effect on probability of growing grass pea. Households who have large family size are likely to be more food insecure and vulnerable to drought impacts. Thus, they often shift to grass pea, which can even grow under harsh climatic conditions.

Distance to market centres. Distance to market centres was controlled in the selection equation but dropped from the outcome equation and it was found to have significant $(P<0.01)$ and negative effect on farmers' choice to grow grass pea. Our findings indicated that as distance to market increases, the probability of growing grass pea decreases significantly. This is likely because grass pea is also a cash crop (besides being a household food item) and hence better access to market increases the probability of growing the crop.

\section{Conclusion}

Grass pea is cultivated in the present study area to be used as human food and livestock feed. Its continuous consumption by human has severe consequences of health (lathyrism) and socioeconomic problems. Irrespective of this, smallholder farmers in the highlands of Ethiopia continue to produce grass pea and many include it in their regular diet. In this context, our study was focused on understanding key determinants of land allocation to grass pea production and its consumption. Our results revealed that smallholder farmers' land allocation to grass pea production is determined by a number of socioeconomic and environmental factors. We identified that factors such as share cropping arrangement, gender of a household head, size of household land and household wealth had positive impacts, whereas frequency of extension services, levels of primary education, distance to market centres and household size/exposures to food insecurity negatively influenced land allocation to grass production and its consumption. In many parts of Ethiopia and the study area in particular, livestock feed predominantly depends on crop residue where straw of grass pea was the most preferred one; this often motivates farmers to engage in grass pea production. The regular consumption of grass pea grain by people in its different forms has caused health related and associated socioeconomic problems. Based on these findings, we provide a number of policy recommendations. First, more efforts are required to increase awareness on health problems of grass pea consumption. Second, local farmers should be provided with necessary knowledge and technologies to diversify their crop production and food diet. Specific programmes and policy support are required to strengthen education, health and agricultural extension services for the farmers to promote crop diversification such as through production of other types of pulse crops, which do not have negative human health implications and adapting to local environments. This may include the cultivation of other pulses such as chick pea, which has similar agro-ecological requirements to grass pea; thus can well thrive in the present study area and elsewhere in similar environments of Ethiopia. Third, there should be a policy shift towards better availability of credit services and enhanced access to agricultural inputs such as fertilisers. Fourth, better marketing service arrangements and accessibility for selling other types of locally produced crops will help in reducing dependency of local people on grass pea as a cash crop. Fifth, expansion of family planning education will reduce the size of household and thereby reducing exposures of family members to food insecurity (through better per capita production). These further need improving wealth of households and advising local people to maintain and develop good saving and wise use of credit culture. Sixth, engaging poor households in off-farm income generating activities could be the other option so that in the long term they can create farming capital like plough ox and cash to buy required agricultural inputs. Finally, promotion of planting nutritious forage varieties can also help obtaining quality livestock feed, thereby, reducing the interest of local people to produce grass pea residue as a source of forage too. For this, we recommend developing alternative livestock breed, feed and forage production systems for the study area and Ethiopia as a whole.

While the presented study had some limitations in terms of spatial and temporal dimensions, insights gained from the case study can also be useful to other contexts elsewhere, particularly in other parts of Ethiopia. First, the study covered only two adjoining districts, which are affected by lathyrism and failed to include other districts in the region and also other parts of Ethiopia experiencing similar problem. Second, we used crosssectional data, which may not account for temporal dimension (e.g., time series or cultivation pattern over years). We recommend expanding this study both in time and space to make the problem a national agenda and come up with national level policy recommendations to avoid and reduce dependency on grass pea production and consumption.

\section{Data availability}

Data analysed are referred to in the paper. 
Received: 14 February 2020; Accepted: 18 August 2020;

Published online: 03 September 2020

\section{References}

Abd El Moneim AM, Saxena MC, El-Saleh A, Nakkoul H (2000) The status of breeding grass pea (Lathyrus sativus L.) for improved yield and quality at ICARDA. In: Tekle Haimanat R, Lambien F (eds). Lathyrus and lathyrism, a decade of progress. University of Ghent, Ghent, Belgium, pp 81-83

Atnaf M, Tesfaye K, Dagn K (2015) The importance of legumes in the Ethiopian farming system and overall economy: an overview. Am J Exp Agric 7 (6):347-358

Chibwana C, Fisher M, Shively G (2012) Cropland allocation effects of agricultural input subsidies in Malawi. World Dev 40(1):124-133

Cochran WG (1963) Sampling techniques. John Wiley \& Sons, Inc, New York, NY, p 413

Coxhead I, Demeke B (2004) Panel data evidence on upland agricultural land use in the Philippines: can economic policy reforms reduce environmental damages? Agric Econ 86(5):1354-1360

CSA/Central Statistical Authority of Ethiopia (1996) Agricultural sample survey 1995/1996 (1988 E.C.), vol I, area and production for major crops (privet peasant holdings, Meher season), statistical bulletin 152, Addis Ababa

CSA (2008) Summery and statistical report of the 2007 population and housing censes: population size by age and sex. CSA, Addis Ababa

CSA (2018) Agricultural sample survey 2016/2017 (2010 E.C.), vol I, area and production for major crops (privet peasant holdings, Meher season), statistical bulletin 586, Addis Ababa

Damene S (2014) Lathyrism in Dawnt Woreda: a paper presented (unpublished) on regional level awareness creation workshop on lathyrism, 6th-7th of October, 2014 Ethio-Star hotel, Bahir Dar town, Ethiopia. The news published on http:// reliefweb.int/report/ethiopia/ethiopia-grass-pea-blessing-and-curse

Dixit PG, Parihar AK, Bohra A, Singh PN (2016) Achievements and prospects of grass pea (Lathyrus sativus L.) improvement for sustainable food production. Crop J 4:407-416

FAO/UNDP (1984) Ethiopian geomorphology and soils (1:1,000,000 scales). Assistance to Land Use Planning, Addis Ababa

Fikre A, Yami A, Kuo Y, Ahmed S, Gheysen G (2010) Effect of methionine supplement on physical responses and neurological symptoms in broiler chicks fed grass pea (Lathyrus sativus)-based starter ration. Food Chem Toxicol 48 (1):11-17

Gebresilassie L, Bekele A (2015) Factors determining allocation of land for improved wheat variety by smallholder farmers of northern Ethiopia. Dev Agric Econ 7(3):105-112

Getahun H, Mekonnen A, TekleHaimanot R, Lambein F (1999) Epidemic of neurolathyrism in Ethiopia. Lancet 54(9175):306-307

Getahuna H, Lambein F, Vanhoorn (2002) Neurolathyrism in Ethiopia: assessment and comparison of knowledge and attitude of health workers and rural inhabitants. Social Science. Medicine 54:1513-1524

Girma A, Tefera B, Dadi L (2011) Grass Pea and Neurolathyrism: Farmers' perception on its consumption and protective measure in North Shewa, Ethiopia. Food Chem Toxicol 49:668-672

Greig L (2009) An analysis of the key factors influencing farmer's choice of crop, Kibamba ward, Tanzania. Agric Econ 60(3):699-715

Heckmann JJ (1979) Sample Selection Bias as a Specification Error. Econometrica 47(1):153-161

Hillocks RJ, Maruthi MN (2012) Grass pea (Lathyrus sativus): Is there a case for further crop improvement? Euphytica 186:647-654

Hurni H (1998) Agro-ecological belts of Ethiopia: Explanatory notes on three maps at a scale of 1:1,000,000. Research report, Soil Conservation Research Program, Addis Ababa

Kassie M (2011) Economic and environmental benefits of forage legume-cereal intercropping in the mixed farming system: a case study in West Gojam, Ethiopia. EDRI. Ethiopian Development Research Working Paper 005, Addis Ababa, Ethiopia, pp. 9-12

Kumar S, Bejiga G, Ahmed S, Nakkoul H, Sarker A (2011) Genetic importance of grass pea for low neurotoxin (ODAP) content. Food Chem Toxicol 49 (3):589-600

Mwaura FM, Adong A (2016) Determinants of households' land allocation for crop production in Uganda. J Sustain Dev 9(5):229-246

Nguyen TT, Nguyen LD, Lippe RS, Grote U (2017) Determinants of farmers' land use decision-making:comparative evidence From Thailand and Vietnam. World Dev 89:199-213

Oluwole OSA (2015) El Niño-southern oscillations and lathyrism epidemics. Front Environ Sci 3(60):1-11
Rashid S, Chilot Yirga C, Behute B, Lemma S (2010) Pulses value chain in Ethiopia: Constraints and opportunities for enhancing exports. IFPRI Working paper. pp. $9 \& 26$

Siddique KHM, Hanbury CL, Sarker A (2006) Registration of 'Ceora' grass pea. Crop Sci 46:986-986

Siddique KHM, Loss SP, Herwig SP, Wilson JM (1996) Growth, yield and neurotoxin (ODAP) concentration of three Lathyrus species in Mediterranean type environments of Western Australia. Aust J Exp Agric 36:209-218

Singh M, Upadhyaya HD, Bisht IS (2013) Genetic and genomic resources of grain legume improvement. Jamestown Road 32, London NW1 7BY, UK; 225 Wyman Street, Waltham, MA 02451, USA

Taffesse AS, Dorosh P, Asrat S (2011) Crop production in Ethiopia: regional patterns and trends. Working paper 16 of Development Strategy and Governance Division, International Food Policy Research Institute, Ethiopia Strategy Support Program II, Ethiopia

Tekle K (1999) Land degradation problems and their implications for food shortage in south Wello, Ethiopia. Environ Manag 23(4):419-427

Tekle-Haimanot R, Feleke A, Lambein F (2005) Is lathyrism still endemic in northern Ethiopia?-The case of Legambo Woreda (district) in the South Wollo Zone, Amhara National Regional State. Ethiop J Health Dev 19 (3):230-236

Thulin M (1983) Leguminosae of Ethiopia. Biology 68:1-23

UNESCO (2015) National Commissions for UNESCO: annual report, 2015, accessed from https://unesdoc.unesco.org/ark:/48223/pf0000244391

Urga K, Fufa H, Husain A (2005) Evaluation of lathyrus sativus cultivated in Ethiopia for proximate composition, minerals, B-ODAP and anti-nutritional components. African. J Food Agric Nutr Dev 5(1):1-15

Woldeamanuel WY, Hassan A, Zenebe G (2012) Neurolathyrism: two Ethiopian case reports and review of the literature. J Neurol 259:1263-1268

World Bank (2018) Ethiopia Economy 2018, CIA World Factbook accessed on November 2018 from https:/www.indexmundi.com/ethiopia/economy_profile. html.

Wu J, Brorsen BW (1995) The impact of government policies and land characteristics on cropping patterns. Can J Agr Econ 43:87-104

Yang H, Zhang X (2005) Considerations on the reintroduction of grass pea in China Hui- Lathyrus. Lathyrism Newsletter 4:22-26

Yazici N, Bilir N (2017) Aspectual fertility variation and its effect on gene diversity of seeds in natural stands of Taurus cedar (Cedrus libani A. Rich.). Int J Genom 2017:1-5

\section{Acknowledgements}

We are thankful to the Office of Vice President for Research and Technology Transfer of Addis Ababa University (Ethiopia) for funding the data collection.

\section{Competing interests}

The authors declare no competing interests

\section{Additional information}

Supplementary information is available for this paper at https://doi.org/10.1057/s41599020-00576-x.

Correspondence and requests for materials should be addressed to S.D.

Reprints and permission information is available at http://www.nature.com/reprints

Publisher's note Springer Nature remains neutral with regard to jurisdictional claims in published maps and institutional affiliations.

Open Access This article is licensed under a Creative Commons Attribution 4.0 International License, which permits use, sharing, adaptation, distribution and reproduction in any medium or format, as long as you give appropriate credit to the original author(s) and the source, provide a link to the Creative Commons license, and indicate if changes were made. The images or other third party material in this article are included in the article's Creative Commons license, unless indicated otherwise in a credit line to the material. If material is not included in the article's Creative Commons license and your intended use is not permitted by statutory regulation or exceeds the permitted use, you will need to obtain permission directly from the copyright holder. To view a copy of this license, visit http://creativecommons.org/ licenses/by/4.0/

(C) The Author(s) 2020 